\title{
Okul Yöneticilerinin Öğretmenlere Yönelik Metaforik
}

\begin{abstract}
Algilari*
Sevim Sinem AYDEŞ* $\quad$ Uğur AKIN***

Öz

$\mathrm{Bu}$ araştırmanın amacı, okul yöneticilerinin öğretmenlere yönelik algılarını metaforlar yoluyla belirlemektir. Nitel yöntemin tercih edildiği araştırmada olgubilim deseni kullanılmıştır. Çalışma grubu 2013-2014 eğitim ve öğretim yılı güz döneminde Tokat ve Eskişehir il merkezlerindeki eğitim kurumlarında görev yapan 73 okul yöneticisinden oluşmaktadır. Veriler araştırma kapsamında geliştirilen görüşme formu ile toplanmış, katılımcılarla yüz yüze görüşmeler yapılmıştır. Okul yöneticilerine (1) göreve yeni başlayan, (2) emekliliği yaklaşmış, (3) bekâr, (4) evli ve (5) derste bulunan öğretmenleri neye benzettikleri ve bunun nedenleri sorulmuştur. Araştırma bulguları, okul yöneticilerinin mesleğe yeni başlayan öğretmenlere ilişkin ürettikleri metaforların acemi, güçlü-verimli ve idealist temaları altında toplandığını göstermektedir. Emekliliği yaklaşan öğretmenler ise bir yandan verimsiz, bir yandan da güçlü ve duygusal olarak algılanmaktadır. Katılımcılar bekar öğretmenleri güçlü, seçici ve özgür olarak betimlerken; evli öğretmenler bir yandan verimsiz bir yandan güçlü, aynı zamanda duygusal ve koruyucu olarak nitelendirilmektedir. Okul yöneticilerinin derste bulunan öğretmenlere yönelik ürettikleri metaforlar ise dersteki öğretmenlerin güçlü, gözde, öğretici ve önder olarak algılandıklarını göstermektedir.
\end{abstract}

Anahtar Kelimeler: Okul Yöneticisi, Öğretmen, Metafor.

\section{School Administrators' Metaphorical Perceptions about}

\section{Teachers}

\begin{abstract}
The aim of this research is to determine the teacher perceptions of school administrators through metaphors. Phenomenological design was utilized in this research in which qualitative method was preferred. Study group is consisted of 73 school administrators working at Tokat and Eskişehir in the 2013-2014 academic years, fall semester. Data was gathered through the interview form which was developed for this research and face to face interviews were conducted. It is asked to administrators that to what were they liken (1) new beginning, (2) about retirement, (3) single, (4) married, and (5) in-class teachers and why. Results show that, the metaphors school administrators generated for new beginning teachers are grouped under the themes of novice, powerfulproductive, and idealist. Teachers about retirement are perceived unfruitful on one hand, powerful and emotional on the other hand. While participants described single teachers as powerful, selective, and free; married teachers are characterized as unfruitful on one hand and powerful on
\end{abstract}

\footnotetext{
* Bu makale, Gaziosmanpaşa Üniversitesi Eğitim Bilimleri Enstitüsü'nde Yrd. Doç. Dr. Uğur Akın danışmanlığında tamamlanan yüksek lisans tezinden üretilmiştir.

** Öğretmen, Eskişehir İl Milli Eğitim Müdürlüğü, sinem.aydes@gmail.com

${ }^{* * *}$ Yrd. Doç. Dr., Gaziosmanpaşa Üniversitesi Eğitim Fakültesi, Eğitim Bilimleri Bölümü, akinuur@gmail.com
} 
the other hand, also emotional and protective in the same time. The metaphors school administrators generate for teachers in the classroom showed that these teachers are perceived as powerful, favorite, didactic, and leader.

Keywords: School Administrator, Teacher, Metaphor

\section{GíRIŞ}

Eğitim insanı, insan olma yolunda geliştiren temel etmendir. İnsanoğlu hayatının her evresinde eğitim ile iç içedir. Eğitimin olmazsa olmazı ise öğretmendir (Arıkan, 2012). Türkiye'de öğretmenlik mesleği, hak ettiği itibar ve statüde görülmemektedir (Çelikten, Şanal ve Yeni, 2005). Öğretmenlik, herkesin yapabileceği bir meslek değildir. Buna rağmen öğretmenlik mesleği herkesin yapabileceği, diğer alanlarda iş bulamamış, hayatta biraz da düş kırıklığına uğramış gençlerin "ekmek kapısı" olarak algılanmıştır (Karagözoğlu, 2003). Ayrıca yakın zamana kadar kutsal bir meslek olarak görülen öğretmenlik, günümüzde ailelerin ve çevrenin "çocuk hiç olmazsa bir öğretmen olsun" biçiminde algıladığı bir meslek halini almıştır (Mustan, 2002: 117). Yapilan araştırmalar da (örn. Yaman, Yaman ve Eskicumalı, 2001) öğretmenlik mesleğinin statüsünün genel olarak düşük olarak algılandığını göstermektedir. Bu örneklerden ve araştırma sonuçlarından hareketle öğretmenliğin, gerek toplum gerekse toplumun bir yansıması olarak Milli Eğitim Bakanlığı, öğrenci velisi, öğrenci ve okul yöneticilerinin gözünde layık olduğu yerden çok aşağılarda yer aldığı ileri sürülebilir. $\mathrm{Bu}$ araştırmada öğretmenlere yönelik var olan algıyı, onları en yakından tanıdığı düşünülebilecek olan okul yöneticilerinin ürettiği metaforlar yoluyla ortaya koymak amaçlanmıştır.

\subsection{Metafor Kavramı}

Metafor, genel olarak insanın dünyayı kavrayışına etki eden bir düşünme ve görme biçimi anlamına gelmektedir (Morgan, 1997: 14). Aristo ile M.Ö. dördüncü yüzyılda ortaya çıan metafor kavramının, retorik bir araç olduğu ifade edilmektedir. Aristo metaforu iki anlamda kullanmıştır. Buna göre metafor bir yönüyle, konuşmada çağrışım, karşılaştırma ve benzerliklerin kullanıldığı tüm benzetmeleri ifade etmektedir. Diğer yönüyle metafor, karşlaştırılan iki şeyin özdeşleştirilmesi ile benzerliğin ifade edilmesidir (Clarken, 1997). Bireylerin olayları ve olguları, diğer insanlarla ilişkilerini nasıl algıladıkları, düşünme biçimlerini büyük ölçüde etkilemektedir. $\mathrm{Bu}$ yönüyle metaforlar bireylerin kavramsal yapılarının biçimlenmesinde önemli bir yer tutmaktadır (Lakoff ve Johnson, 1980: 103). Metafor kullanımı, bireylerin günlük yaşantısında geçmiş ve şimdiki bağlam arasında köprü kurmaya; var olan bir fenomene tamamen farklı bir perspektiften bakmaya ya da 1şık tutmaya yardımcı olabilmektedir (Levine, 2001). Metafor, karmaşık ve soyut olanı yeni bir görüş açısından görmeye olanak sağlar ve bir takım özelliklerin bilinen bağlamdan bilinmeyenlere transferine yardımc1 olur (Balc1, 1992). Metaforlar, anlatımı süsler ve insanlar metaforun altında yatan anlamı keşfetmekten dolayı memnuniyet duyar (Ortony, Reynolds ve Arter, 1977). Tanımlardan yola çıkarak, metaforların kavramların anlaşılmasını kolaylaştıran etkili birer araç olduğu dile getirilebilir. Sonuç olarak metafor, bilinmeyeni anlamak ve açıklamak için bilinmeyenin bilinenle benzer özelliklerinden yararlanma biçiminde işleyen bir düşünüş tarzı olarak kavramlaştırılabilir.

\section{2. Öğretmen Metaforları}

Öğrenme ve öğretme süreçlerinin temel ögelerinden biri olan öğretmen, öğrenci ile devamlı etkileşim içinde bulunan, eğitim programını uygulayan, öğretimi yöneten ve hem öğrencinin hem de öğretimin değerlendirmesini yapan kişidir (Bircan, 2003: 46). Öğretmen hem okulu hem de sınıfı diri tutan, aynı zamanda öğrencilerde iz bırakan kimsedir. Öğrenciler öğretmenler sayesinde bir hayat görüşü sahibi olurlar (Topses, 2006: 6). Öğretmenin sadece bir tek öğretici rolü değil, birbirine bağımlı ve örtüşen birçok rolü vardır. Öğretmen her şeyden önce bir eğitim uzmanı, aynı zamanda bir yönetici, bir danışman, bir psikolog, bir sosyolog, 
bir rehber, bir lider ve insanı seven duyarlı iyi bir insandır (Demirbolat, 2006). Baltacığolu'na göre (1944), öğretmen yalnızca bir okul çalışanı değildir. Öğretmen, kültür bilinci ve uygarlık bilgisini üzerinde taşıyan, bu yüzden sevilen ve sayılan, inkılâpçı ve tüm bunlara ek olarak da iş sevgisi olup üretici ve ideal sahibi olma özelliklerine sahip kimsedir (Akt. Binbaşığlu, 2005). Elbette bu biçimde çizilen bir öğretmen profili, ideal olanı yansıtmaktadır. Oysa girişte değinildiği üzere var olan durumda öğretmenlere yönelik olumsuz bazı algılar da bulunmaktadır. Var olan öğretmen algısını ortaya koymanın en iyi yollarından biri de metaforları işe koşmaktır.

Metaforlar ve metaforik analizler, eğitim alanında mevcut eğitim uygulamalarını araştırmak ve anlamak için analitik ve betimleyici araçlar olarak kullanılmaktadır. Metaforlar ayrıca, sınıf yönetimi, eğitim yönetimi, rehberlik, okul geliştirme ve genel olarak eğitim alanında bireylerin çeşitli konularda nasıl düşündüklerini ve algilarını betimlemek, problemlere çözüm bulmak ve eğitim uygulamalarındaki problemleri çözmede yeni perspektifler yaratmak için bilgi toplamakta kullanılmaktadır (Balcı, 1999: 35). Metaforlar, çeşitli eğitim paydaşlarının öğretmenlere yönelik algılarını belirlemek üzere de kullanılmaktadır. Clarken'in (1997) araştırması, öğretmenler için arkadaş, otoriter patron, aile, peygamber, doktor, bahçıvan gibi metaforların en yaygın kullanılan metaforlar olduğunu göstermektedir. Tobin ve Tippins (1996) öğretmenler için yaygın kullanılan metaforlardan birinin bahçıvan metaforu olduğunu belirtmektedir. Patchen ve Crawford (2011), öğretmenlerin bir ürün ortaya koyan (örn. sanatçı), bir performans sergileyen (örn. popstar) ve bir hedefe ulaşmaya çalışan bireyler (örn. dağcl) olarak betimlendiklerini tespit etmişlerdir. Türkiye'de Çelikten (2006) öğretmen metaforlarını kültür bağlamında ele aldığı araştırmada öğretmenlerin arkadaş, sıkı otorite, anne-baba, bahçıvan, inci istiridyesi ve doktor metaforlarıyla betimlendiğini tespit etmiştir. Bu araştırmada hem arkadaş hem de sıkı otorite metaforlarının elde edilmesi öğretmene bakışın oldukça farklılaşabildiğini ortaya koymaktadır. Ayrıca anne-baba metaforları da Türk kültürünün paternalist özelliklerinin araştırmaya yansıdığını göstermektedir. Alanyazında öğretmen adaylarının öğretmenlere yönelik metaforik algılarını ele alan araştırmalar bulunmaktadır (Aydın ve Pehlivan, 2010; Eren ve Tekinarslan, 2013; Kalyoncu, 2012; Ocak ve Gündüz, 2006; Oğuz, 2009; Pektaş ve Kıldan, 2009; Saban, 2011; Saban, Koçbeker ve Saban, 2006). Bunlardan Ocak ve Gündüz'ün (2006) araştırması, öğretmen adaylarının öğretmenliğe ilişkin bilinç düzeylerinin öğretmenlere bakışını farklılaştırdığını göstermiştir. Buna göre, öğretmenleri ebeveyn metaforuyla betimleyen öğretmen adayları, öğretmenlik mesleğine giriş dersini aldıktan sonra bahçıvan ve güneş metaforlarını tercih etmişlerdir. Saban'ın (2004) sınıf öğretmeni adaylarının öğretmen algısını ele aldığı çalışmada katılımcıların büyük bir çoğunluğunun öğretmeni bahçıvan metaforuyla betimlediği tespit edilmiştir. Cerit (2008) öğretmen, öğrenci ve okul yöneticilerinin sahip olduğu öğretmen metaforlarını ele aldığı araştırmada öğretmenlerin, bilgi kaynağı ve dağıtıcısı, anne/baba, arkadaş, rehber ve çevresini aydınlatan kişi metaforlarıyla betimlendiğini tespit etmiştir. Ayrıca araştırmada bahçıvan, otoriter kişi, bakıcı, gardiyan, yıkıcı ve zarar verici kişi metaforlarının tercih edilmediği tespit edilmiştir. $\mathrm{Bu}$ araştırma öğretmen algısının olumlu metaforlarla dile getirildiğini göstermektedir. Yılmaz, Göçen ve Yılmaz (2013) öğretmen adaylarının öğretmen algısını ele aldığı araştırmada öğretmenlerin, anne-baba, aile, bahçıvan, rehber, 1şık, çoban gibi metaforlarla betimlendiğini tespit etmiştir. Öğretmen adaylarının oluşturduğu metaforlar şekillendirici, yol gösterici, bilgi kaynağı, statüsü olmayan, esnek, model ve kutsal bir iş yapan öğretmen kategorileri altında toplanmıştır. 


\subsection{Okul Yöneticilerinin Öğretmenlere İlişkin Metaforik Algıları}

Okul yöneticilerinin öğretmenlere ilişkin metaforik algılarının iki açıdan önemli olduğu düşünülebilir. Birincisi, okul yöneticisi okulu öğretmenlerle birlikte yönetmektedir. Bu süreçte, hakkında olumlu bir algıya sahip olduğu öğretmenlerle çalışmak, yönetim açısından daha olumlu çıktılar üretilmesine katkı sağlayabilir. İkincisi, var olan öğretmen algısını en doğru biçimde ortaya koyabilmek için, öğretmenlere en yakın veri kaynaklarından biri olan okul yöneticilerinin görüşleri görece daha kapsayıcı ve isabetli olabilir.

Yıldırım, Ünal ve Çelik'in (2011) araştırmasında okul yöneticilerinin ürettikleri metaforlar, öğretmenleri daha çok fedakâr, aydınlatıcı, biçimlendirici ve aynı zamanda yetkisiz olarak algıladıklarını göstermektedir. Türkiye'de bu amaçla yapılan en kapsamlı araştırmalardan biri Cerit'in (2008) öğretmen, öğrenci ve okul yöneticilerinin algılarına göre öğretmen metaforlarını ele aldığı çalışmadır. Bu araştırmanın sonuçlarına göre okul yöneticilerinin önemli bir bölümü öğretmenleri melek, bilgi kaynağı ve dağıtıcısı, anne-baba, arkadaş, üretici, rehber, bahçıvan, danışman, heykeltıraş metaforlarıyla betimlemektedir. Diğer taraftan katılımcıların önemli bölümü öğretmenleri bakıcı, hâkim, koç, gardiyan gibi olumsuz metaforlarla betimlemeyi reddetmişlerdir. Cerit'in (2008) araştırması konuyu oldukça kapsamlı biçimde ele alsa da öğretmenlerin farklı dönem ve durumlarına ilişkin algılar farklılaşabilecektir. Örneğin göreve yeni başlayan ya da emekliği yaklaşmış öğretmenlere yönelik algılar farklılık gösterebilir. Araştırmalar öğretmenlerin örgütsel sinizm (Kalağan ve Güzeller, 2010), tükenmişlik (Akın ve Oğuz, 2010) düzeyleri gibi okula ilişkin algılarını farklılaştırabilecek değişkenlerin kıdemlerine göre farklılaştığını göstermektedir. Öğretmenin bekâr ya da evli olması da benzer biçimde algıyı farklılaştırabilir. Araştırmalar evli öğretmenlerin okullarına normatif bağlılıklarının daha yüksek olduğunu (Kurşunoğlu, Bakay ve
Tanriöğen, 2010) ve bu öğretmenlerin çocukları daha çok sevdiğini (Gelbal ve Duyan, 2010) göstermektedir. Yine derste olan öğretmen algısı genel öğretmen algisından farklı olacaktır. Bu araştırmada okul müdürlerinin öğretmenlerin genel davranışlarına yönelik algıları değil, derste, öğrenci ile öğrenme öğretme sürecinde etkileşimde bulunan öğretmene yönelik algısı ele alınmıştır. Bu açıdan bakıldığında, bu araştırmayı alanyazından farklılaştıran yönü, genel öğretmen algısı üzerinden değil, farklı bağlamlardaki öğretmen algısı üzerinden hareket ediyor olmasıdır. $\mathrm{Bu}$ bakımdan araştırmanın alanyazına katkı sağlayacağı ve uygulamacılara farklı bir pencere açacağı düşünülmektedir.

\subsection{Araştırmanın Amacı}

$\mathrm{Bu}$ araştırmanın amacı okul yöneticilerinin öğretmenlere yönelik metaforik algılarını incelemektir. Bu amaç çerçevesinde aşağıdaki sorulara yanıt aranmıştır: Okul yöneticilerinin;

1. Göreve yeni başlayan öğretmenlere yönelik metaforik algıları nasıldır?

2. Emekliliği yaklaşmış öğretmenlere yönelik metaforik algıları nasıldır?

3. Bekâr öğretmenlere yönelik metaforik algıları nasıldır?

4. Evli öğretmenlere yönelik metaforik algıları nasıldır?

5. Derste bulunan öğretmenlere yönelik metaforik algıları nasıldır?

\section{YÖNTEM}

\subsection{Araştırmanın Modeli}

Nitel araştırma yaklaşımı doğrultusunda tasarlanan bu araştırmada olgu bilim (fenomenoloji) deseni kullanılmıştır. Araştırma verilerinin toplanmasında görüşme tekniğinden yararlanılmıştır. Nitel yöntem ve görüşme tekniği ile üzerinde araştırma yapılan kişi ya da grupların deneyimlerinden doğan anlamları sistematik olarak inceleyebilmek olanaklı hale gelmektedir. Ayrıca nitel yaklaşım dâhilinde 
insanların duygu, düşünce süreçlerini daha iyi anlayabilmek ve bulgulardan elde edilebilecek kuramların, birtakım kavramların bir araya getirilmesiyle gerçeği daha iyi yansıtmak mümkün olmaktadır (Yıldırım ve Şimşek, 2011). Nitel araştırma yaklaşımları içerisinde, metaforların ya da diğer bir deyişle mecazların kullanımı, bireylerden derinlemesine görüş alınması ve düşünce, duygu sistemlerinin anlaşılması açısından önem taşımaktadır (Girmen, 2007: 75). Bu araştırmada da okul yöneticilerinin belirli dönem ve durumlardaki öğretmen algılarını yansıtmak üzere birer metafor üretmeleri ve oluşturulan metaforun sebebini açıklamaları istenmiştir.

\section{2. Çalışma Grubu}

Araştırmanın çalışma grubunu, 2013-2014 eğitim ve öğretim yılı güz döneminde araştırmacıların görev yerlerinin bulunduğu iller olan Tokat il merkezi ve Eskişehir il merkezindeki eğitim kurumlarında görev yapan Tokat ilinden 37, Eskişehir ilinden 36 olmak üzere toplam 73 okul yöneticisi oluşturmaktadır. Araştırmada kolay ulaşllabilir örnekleme tekniğine uygun olarak çalışma grubu seçilmiştir. Kolay ulaşılabilir örnekleme genellikle pratik ve daha az maliyetli olduğu için tercih edilmektedir (Yıldırım ve Şimşek: 2011). Bu araştırmada da benzer nedenlerle bu teknik işe koşulmuştur. Katılımclardan 7 okul yöneticisi kadın, 66 okul yöneticisi erkektir. 1-10 yıl yöneticilik yapanların sayısı 54, 11-20 yıl yöneticilik yapanların sayısı 15, 21 yıl ve üstü yöneticilik yapanların sayısı 4 'tür. Okul yöneticilerinden lisans mezunlarının sayısı 64, yüksek lisans mezunlarının sayısı 9'dur. Çalışma grubunda 26-30 yaşları arasında 7, 31-40 yaşları arasında 43 ve 41 yaş üstü 23 okul yöneticisi bulunmaktadır.

\subsection{Veri Toplama Aracı}

Veri toplama aracı olarak açı uçlu sorulardan oluşan yarı yapılandırılmış bir görüşme formu kullanılmıştır. Görüşme formu iki bölümden oluşmaktadır. Birinci bölümde okul yöneticilerine ait kişisel bilgilerle (yaş, cinsiyet, öğretmenlik kıdemi, yöneticilik kıdemi) ilgili sorular yer almaktadır. İkinci bölümde okul yöneticilerinin çeşitli dönem ve durumlardaki öğretmen algılarını belirlemeye yönelik (öğretmen göreve yeni başladığında, emekliliği yaklaştı̆̆ında, bekâr ise, evli ise, derste) beş adet boşluk doldurma sorusu bulunmaktadır. Boşluk doldurma soruları, "Öğretmen göreve yeni başladığında ... gibidir; çünkü ..." biçiminde hazırlanmıştır.

Görüşme soruları hazırlanmadan önce araştırma konusu ile ilgili alan yazın taraması yapılmıştır. Alan yazın taramasından sonra görüşme formunda yer alması düşünülen sorular belirlenmiştir. Oluşturulan taslak form eğitim yönetimi alanından nitel araştırma deneyimi bulunan üç uzmanın görüşüne sunulmuştur. Uzman görüşleri doğrultusunda formda kalması ve çıkarılması gereken sorular belirlenmiştir. Ayrıca sorularla ilgili açılık, anlaşılırlık, kapsayıcılık, amaca uygunluk gibi konularda getirilen öneriler dikkate alınarak görüşme formuna son şekli verilmiştir.

\subsection{Veri Toplama Süreci}

Uygulamayı kabul eden okul yöneticileri ile yöneticilerin görev yaptıkları kurumlarda yüz yüze görüşülmüsştür. Katılımcılara araştırmanın amacından söz edilmiş ve kişisel bilgilerinin gizli tutulacağına ilişkin ayrıntılı açıklamalar yapılmıştır. Görüşmeler Ekim 2013-Ocak 2014 tarihleri arasında gerçekleştirilmiştir. Görüşme esnasında araştırma ile ilgili bilgiler verilmiştir. Soruların araştırmanın amacına uygun biçimde yanttlanabilmesini sağlayabilmek için, sorular katılımcılara araştırmacı tarafindan yöneltilmiş, anlaşılmayan noktalara müdahale edilmiştir. Gönüllülük esası göz ardı edilmeden sürecin verimliliği dikkatle takip edilmiştir. Araştırmada katılımcıların kendilerini rahat hissedebileceği ve görüşlerini içtenlikle açılayabilecekleri bir ortam sağlanmasına özen gösterilmiştir.

\subsection{Verilerin Analizi}

Araştırmada toplanan veriler üzerinde nitel veri analizi tekniklerinden içerik analizi kullanılmıştır. İçerik analizi, toplanan verilerin derinlemesine analizini gerektirir ve bu sayede önceden belli olmayan temaların ortaya çıkarılması sağlanır. İçerik analizi yoluyla 
birbirine benzeyen veriler belirli kavramlar ve temalar çerçevesinde bir araya getirilerek okuyucunun anlayabileceği bir şekilde düzenlenir, yorumlanır (Yıldırım ve Şimşek, 2011). İçerik analizi mesajda bireyi görünmeden etkileyen öğelerin belirlenmesi; ilk bakışta algılanan içeriğin yerine gizil, üstü kapalı içeriğin ortaya çıkarılmasıdır (Bilgin, 2000).

Analiz sürecinde öncelikle kullanılabilir yarı yapılandırılmış görüşme formlarını belirlemek için eleme işlemi yapılmıştır. Toplanan formların analize alınabilmesi için görüşme formunun birinci bölümündeki demografik bilgilerin tam olarak doldurulmuş olması gerekmektedir. $\mathrm{Bu}$ nedenle toplanan görüşme formlarının birinci bölümleri incelenerek eksik veri bulunan görüşme formları elenmiştir. Eleme işleminden sonra toplanan formlardan değerlendirmeye alınacak 73 adet görüşme formuna ulaşılmıştır. Arkasından veriler Microsoft Excel programına aktarılmıştır. Böylelikle elde edilen metaforları ve nedenlerini toplu olarak görmek ve gruplandırmak daha kolay hale getirilmiştir. Sonrasında okul yöneticilerinin verdiği cevaplar incelenerek, metafor oluşturmayan, herhangi bir benzetme açılaması yapılmayan, yarım bırakılan, alakasız ilişkilerle oluşturulan cevaplar elenmiştir. Eleme işleminden sonra her bir soru için benzer cevaplar bir araya getirilerek aynı temayı taşıyan gruplar oluşturulmuştur. Gruplama işlemi yapılırken oluşturulan metaforlardan ziyade onun gerekçesini açıklayan "çünkü" kısmı dikkate alınmıştır. Bunun nedeni oluşturulan metaforla anlatılmak, verilmek istenen düşüncenin "çünkü" ile başlayan kısımda olmasıdır. İlgili veriler ayrıntılı olarak bulgular kısmında verilmiştir.

Nitel bir çalışma olan bu araştırmada geçerliliği ve güvenirliği sağlamak için araştırmanın tüm süreci ayrıntılarıyla rapor edilmiştir. Ayrıca araştırmanın iç güvenirliği konusunda ön uygulama bizzat araştırmacı tarafından yapılarak okul yöneticilerinin soruları algılayış şekilleri ve sordukları sorular hakkında gözlem yapılmıştır. Hem uygulama sırasında gelen sorular hem de görüşme formuna verilen cevaplar incelenerek metafor üretilemeyen sorular ve benzer anlamlara gelen sorularda elemeler yapılmıştır. Ayrıca ön uygulama sonucunda yapılan düzeltmelerden sonra tekrar uzman görüşü alınmıştır. Son olarak, bir başka alan uzmanının elde edilen metaforları temalara ayırması istenmiş ve bu bağımsız süreçte oluşturulan temalarla araştırma sürecinde oluşturulan temaların büyük ölçüde uyuştuğu görülmüştür.

\section{BULGULAR}

\subsection{Mesleğinin İlk Yıllarındaki Öğretmenlere İlişkin Metaforlar}

Okul yöneticilerine mesleğinin ilk yıllarındaki öğretmenleri neye benzettikleri ve bunun nedenleri sorulmuş, üretilen metaforlar kategorilere ayrılarak Tablo 1'de sunulmuştur. 
Tablo 1. Mesleğinin İlk Yıllarındaki Öğretmenlere Yönelik Metaforik Algılar

\begin{tabular}{|c|c|c|}
\hline & & Nedenleri \\
\hline & $\begin{array}{l}\text { Masum ve savunmasız kuş } \\
\text { Bebek, Çocuk } \\
\text { Sudan çıkmış balık } \\
\text { Ürkek ceylan, Ürkek tavşan, Şaşkın } \\
\text { ördek, Polyanna, Pısırık kedi, Yeni gelin, } \\
\text { Gonca, Beyaz bir sayfa } \\
\text { Deli fişek, Acemi yüzücü, Öğrenci, } \\
\text { Şaşkın insan, Hevesli ve heyecanlı insan, } \\
\text { Yeni açmış çiçek, Yeni transfer futbolcu, } \\
\text { Kırlangıç, Cam }\end{array}$ & $\begin{array}{l}\text { lk } \\
\text { eyen bir } \\
\text { n } \\
\text { henüz } \\
\text { henüz }\end{array}$ \\
\hline $\begin{array}{l}\text { Verimli } \\
\text { Metafor }\end{array}$ & $\begin{array}{l}\text { Aslan } \\
\text { Taze yanan mum, Yaz güneşi, Bomba } \\
\text { Ateş böceği, Süpermen, Bilgi kaynağı, } \\
\text { Yumurtlayacak tavuk, Çağlayan pınar, } \\
\text { Sıfır araba, Kurt }\end{array}$ & \\
\hline & $\begin{array}{l}\text { İdealist Devlet Başkanı } \\
\text { Yayından fırlamış ok, Milli eğitim bakanı, } \\
\text { Malkoçoğlu, Vali }\end{array}$ & $\begin{array}{l}4 \begin{array}{l}\text { Öğretmen ilk yıllarında her şeyi } \\
\text { yapabileceğini ve değiştirebileceğini } \\
\text { düşünür, etrafını aydınlatmaya } \\
\text { çalışır, idealisttir, her şeyi bildiğini } \\
\text { zanneder ve yapmak istediği çok şey } \\
\text { vardır. }\end{array} \\
\end{array}$ \\
\hline \multicolumn{3}{|c|}{ 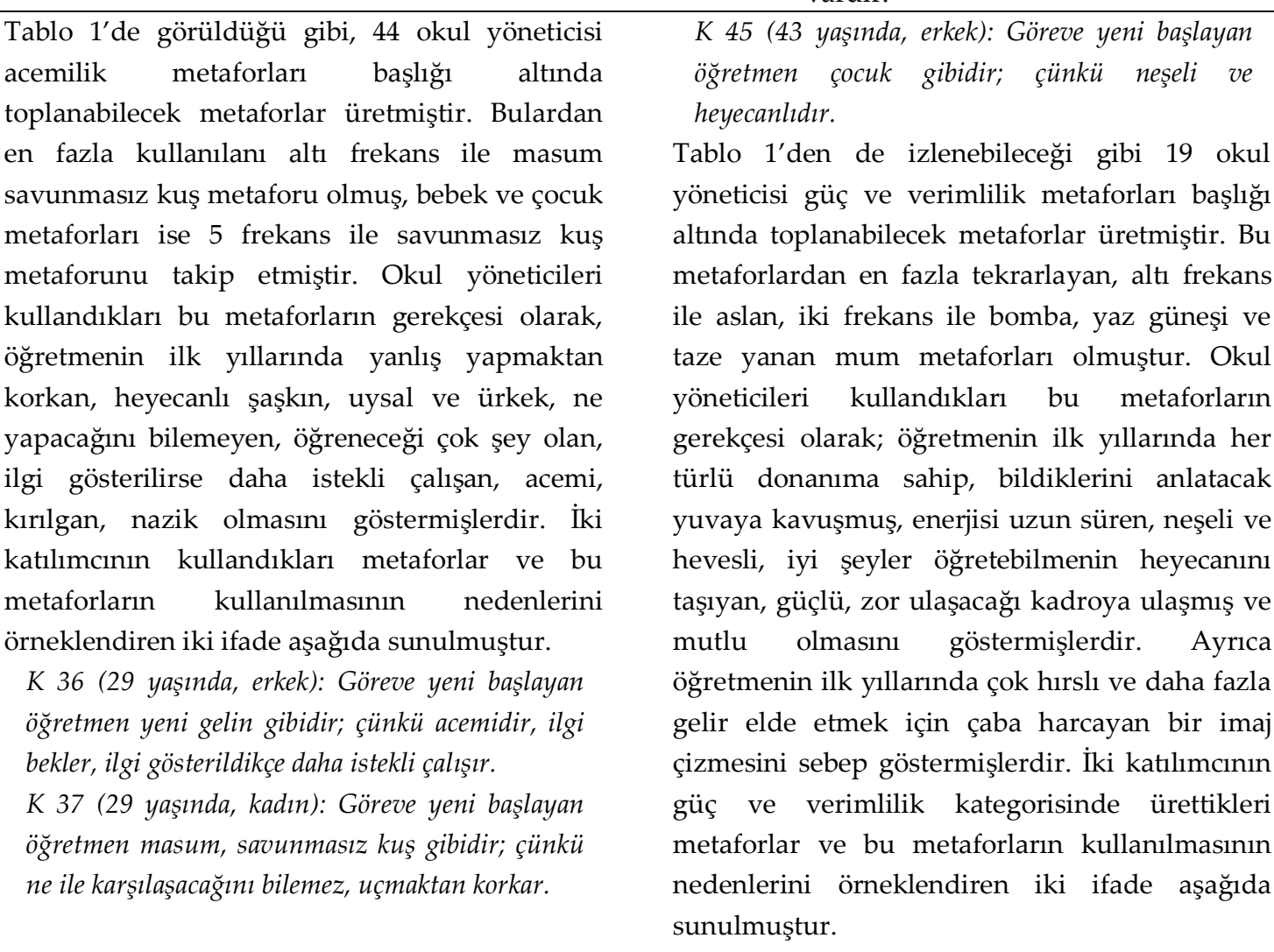 } \\
\hline
\end{tabular}


K 1 (32 yaşında, erkek): Göreve yeni başlayan öğretmen aslan gibidir; çünkü her şeye gücünün yeteceğini sanır.

K 12 (35 yaşında, erkek): Göreve yeni başlayan ögrretmen yumurtlayacak tavuk gibidir; çünkü bildiklerini anlatacak yuvaya kavuşmuştur.

K 32 (38 yaşında, erkek): Göreve yeni başlayan öğretmen Süpermen gibidir; çünkü heyecanla işe başlar.

Yine Tablo 1'den izlenebileceği gibi 8 okul yöneticisi ilk yıllarındaki öğretmene ilişkin idealizm metaforları başlığı altında toplanabilecek toplam beş metafor üretmiştir. Bu metaforlardan en fazla kullanılan dört frekans ile idealist devlet başkanı olmuştur. Okul yöneticileri kullandıkları bu metaforların şeyi yapabileceğini ve değiştirebileceğini düşünmesini, etrafını aydınlatmaya çalışmasını, idealist olmasını, her şeyi bildiğini zannetmesini gerekçesi olarak öğretmenin ilk yıllarında her

ve yapmak istediği çok şey olmasını göstermişlerdir.

İki katılımcının bu kategoride kullandıkları metaforlar ve bu metaforların kullanılmasının nedenlerini örneklendiren iki ifade aşağıda sunulmuştur.

K 3 (35 yaşında, erkek): Göreve yeni başlayan öğretmen devlet başkanı gibidir; çünkü herkesi her şeyi yönetebileceğini düşünür.

K 15 (39 yaşında, erkek): Göreve yeni başlayan öğretmen Malkoçoğlu gibidir; çünkü her şeyi yapabileceğini düşünür.

K 24 (42 yaşında, erkek): Göreve yeni başlayan öğretmen vali gibidir; çünkü her şeyi bildiğini zanneder.

\subsection{Emekliliği Yaklaşmış Öğretmenlere İlişkin Metaforlar}

Okul yöneticilerine emekliliği yaklaşmış öğretmenleri neye benzettikleri ve bunun nedenleri sorulmuş, üretilen metaforlar kategorilere ayrılarak Tablo 2'de sunulmuştur.

Tablo 2. Emekliliği Yaklaşmış Öğretmenlere Yönelik Metaforik Algılar

\begin{tabular}{|c|c|c|c|}
\hline $\begin{array}{l}\text { Metafor } \\
\text { Kategorileri }\end{array}$ & Metaforlar & $f$ & Nedenleri \\
\hline $\begin{array}{l}\text { Verimsizlik } \\
\text { Metaforları } \\
(n=32)\end{array}$ & $\begin{array}{l}\text { Kaplumbağa, Sönmeye yüz tutmuş mum } \\
\text { Tükenmek üzere olan pil, Jübileyi bekleyen } \\
\text { sporcu, Umursamaz insan } \\
\text { Bitik pil, Hayattan bezmiş insan, İçi geçmiş } \\
\text { portakal, Fil, Kış güneşi, Yelkenleri inmiş } \\
\text { gemi, Kanadı kırılmış kuş, Katı meyve } \\
\text { sıkacağındaki portakal, Bozuk plak, Akkoru } \\
\text { geçecek lamba, Kaplumbağa, Uzatmaları } \\
\text { oynayan futbolcu, Yorgun aslan, Turşu, } \\
\text { Kurumuş meyve, Dede, Bezgin insan, Eski } \\
\text { eşya, Sonbahar, Yorgun savaşçı }\end{array}$ & 1 & $\begin{array}{l}\text { Öğretmen emekliliğe yakın yorgun, } \\
\text { isteksizdir. İstese de harekete } \\
\text { geçemeyen, gelişimi takip edemeyen, } \\
\text { sabrı tükenmiş bir durumdadır. Değişen } \\
\text { mevzuatlarla uğraşmaktan } \\
\text { yorulmuştur. }\end{array}$ \\
\hline $\begin{array}{l}\text { Güç } \\
\text { Metaforları } \\
(n=30)\end{array}$ & $\begin{array}{l}\text { Asırlık çınar, Kurt, Bilgin } \\
\text { Aslan } \\
\text { Olgun bir meyve, Kütüphane, Kömür, } \\
\text { Terhis olacak asker, Bal kovanı, Sergideki } \\
\text { bir tablo, Kurnaz tilki ve şahin, Usta, } \\
\text { Uzman insan, Kök salmış ağaç, Jeneratör, } \\
\text { Ansiklopedi, Üstat, Köklü ağaç, Eksper, } \\
\text { Kitap kurdu, Güçlü insan, Özgüvenli insan, } \\
\text { Gezen tarih }\end{array}$ & 1 & $\begin{array}{l}\text { Çünkü öğretmen emekliliğine yakın } \\
\text { bilgilidir. Donanımlı bir yapıdadır, } \\
\text { yetiştirdiği öğrencileri ile kök salmıştır. } \\
\text { Tecrübeli, güçlü ve birikimli bir imaj } \\
\text { çizer. }\end{array}$ \\
\hline $\begin{array}{l}\text { Duygusallık } \\
\text { Metaforları } \\
(n=3)\end{array}$ & Vedalaşan aşık, Çok mutlu çocuk, Şeker & 1 & $\begin{array}{l}\text { Öğretmen emekliliğe yakın } \\
\text { sevgilisinden ayrılıyor gibi üzgündür, } \\
\text { emeklilik maaşını düşünmektedir, } \\
\text { öğrenciye karşı davranışları daha } \\
\text { şefkatli bir hal almıştır. }\end{array}$ \\
\hline
\end{tabular}


Tablo 2'de görüldüğü gibi okul 32 yöneticisi emekliliğe yaklaşmış öğretmene ilişkin verimsizlik metaforları başlığı altında toplanabilecek toplam yirmi beş metafor üretmiştir. Bu metaforlardan en fazla kullanılan üç frekans ile kaplumbağa ve sönmeye yüz tutmuş mum olmuş, tükenmek üzere olan pil, umursamaz insan, jübileyi bekleyen sporcu metaforları ise iki frekans ile kaplumbağa ve sönmeye yüz tutmuş mum metaforlarını takip etmiştir. Okul yöneticileri kullandıkları bu metaforların gerekçesi olarak öğretmenin emekliliğe yakın yorgun ve isteksiz olmasını, öğretmenin istese de harekete geçemeyen, gelişimi takip edemeyen, sabrı tükenmiş bir durumda bulunmasını ve değişen mevzuatlarla uğraşmaktan yorulmasını göstermişlerdir. İki katılımcının kullandıkları metaforlar ve bu metaforların kullanılmasının nedenlerini örneklendiren iki ifade aşağıda sunulmuştur.

K 1 (32 yaşında, erkek): Emeklilĭği yaklaşmış öğretmen Jübileyi bekleyen sporcu gibidir; çünkü uzatmalarn bitmesini bekler.

K 29 (42 yaşında, erkek): Emekliliği yaklaşmış öğretmen kaplumbağa gibidir; çünkü istese de mevcut durumundan dolayı hizl hareket edemez.

K 34 (33 yaşında, erkek): Emekliliği yaklaşmıs öğretmen kurumuş meyve gibidir; çünkü içindeki aşk çekilmiştir.

Yine Tablo 2' de görüldüğü gibi 30 okul yöneticisi güç metaforları başlı̆̆ı altında toplanabilecek yirmi üç metafora yer vermiştir. $\mathrm{Bu}$ metaforlardan en fazla kullanılan üç frekans ile asırlık çınar, kurt ve bilgin metaforları olmuştur. Okul yöneticileri kullandıkları bu metaforların gerekçesi olarak öğretmenin emekliliğine yakın bilgili olmasını, donanımlı bir yapıda bulunmasını, yetiştirdiği öğrencileri ile kök salmasını dile getirmişlerdir. İki katılımonın kullandıkları metaforları ve bu metaforların kullanılmasının nedenlerini örneklendiren iki ifade aşağıda sunulmuştur.

K 14 (29 yaşında, erkek): Emekliliği yaklaşmış öğretmen asırlık çınar gibidir; tecrübelidir.

K 23 (38 yaşında, erkek): Emekliliği yaklaşmış öğretmen aslan gibidir; çünkü okulun krah odur.

K 26 (35 yaşında, erkek): Emekliliği yaklaşmış öğretmen terhis olacak asker gibidir; çünkü diğer öğretmenlere çaylaklarmış gibi davranır.

Tablo 2'den de izlenebileceği gibi, 3 okul yöneticisi duygusallık metaforları başlı̆̆ı altında toplanabilecek üç metafora üretmiştir. Okul yöneticileri duygu metaforu olarak vedalaşan aşık, çok mutlu çocuk ve şeker metaforlarını kullanmıştır. Okul yöneticileri kullandıkları bu metaforların gerekçesi olarak, öğretmenin emekliliğine yakın sevdiğinden ayrılıyormuşçasına duygusal, emeklilik maaşı düşüncesi ile dolu ve öğrenciye karşı daha şefkatli olmasını göstermişlerdir. İki katılımcının kullandıkları metaforları ve bu metaforların kullanılmasının nedenlerini örneklendiren iki ifade aşağıda sunulmuştur.

K 24 (42 yaşında, erkek): Emekliliği yaklaşmış öğretmen vedalaşan aşık gibidir; çünkü sevgilisinden ayrllyordur.

K 36 (29 yaşında, erkek): Emekliiliği yaklaşmış öğretmen çok mutlu çocuk gibidir; çünkü emekli ikramiyesini düşünür.

K 52 (47 yaşında, erkek): Emekliliği yaklaşmış öğretmen şeker gibidir; çünkü öğrenciye karşı daha şefkatlidir.

\subsection{Bekâr Öğretmenlere İlişkin Metaforlar}

Okul yöneticilerine bekâr öğretmenleri neye benzettikleri ve bunun nedenleri sorulmuş, üretilen metaforlar Tablo 3'te sunulmuştur. 
Tablo 3. Bekâr Öğretmenlere Yönelik Metaforik Algılar

\begin{tabular}{|c|c|c|c|}
\hline $\begin{array}{l}\text { Metafor } \\
\text { Kategorileri }\end{array}$ & Metaforlar & $f$ & Nedenleri \\
\hline $\begin{array}{l}\text { Güç } \\
\text { Metaforları } \\
(n=12)\end{array}$ & $\begin{array}{l}\text { Atom karınca, Süper kahraman, Virüssüz } \\
\text { bilgisayar, Çalışkan bir insan, Saat, Yeni } \\
\text { açan gül, Sıkı dost, Açılmamış motor, } \\
\text { Aslan, İlgili insan, Kurt, Kaya }\end{array}$ & 1 & $\begin{array}{l}\text { Çünkü öğretmen bekâr ise } \\
\text { durmaksızın çabalar, zamanı bol } \\
\text { olduğu için aktif bir şekilde çalışır, } \\
\text { dakiktir böylelikle yönetim için } \\
\text { sorunsuz bir öğretmen imajı çizer. } \\
\text { Yaşı öğrenciye daha yakındır, arkadaş } \\
\text { gibidir, daha ilgilidir. }\end{array}$ \\
\hline \multirow{3}{*}{$\begin{array}{l}\text { Seçicilik } \\
\text { Metaforları } \\
(n=12)\end{array}$} & Radar & 4 & \multirow{3}{*}{$\begin{array}{l}\text { Öğretmen bekâr ise etrafında kendine } \\
\text { uygun birilerini arar, cazibe merkezi } \\
\text { konumundadır dikkat çeker, herkese } \\
\text { alıcı gözle bakar, dış görünüşüne } \\
\text { oldukça önem verir. }\end{array}$} \\
\hline & Şahin & 2 & \\
\hline & $\begin{array}{l}\text { Aday damat, Magazin muhabiri, Avcı, } \\
\text { Galerideki araba, Tavus kuşu, Mıknatıs }\end{array}$ & 1 & \\
\hline \multirow{4}{*}{$\begin{array}{l}\text { Özgürlük } \\
\text { Metaforları } \\
(n=11)\end{array}$} & Turist & 4 & \multirow{4}{*}{$\begin{array}{l}\text { Öğretmen eğer bekâr ise gezmek için } \\
\text { de zamanı çoktur, ekstra çalışmalara } \\
\text { zaman ayırabilir, özgürdür, her } \\
\text { tatilde bir yere gidebilecek enerjisi ve } \\
\text { imkânları vardır. }\end{array}$} \\
\hline & Özgür bir kuş & 3 & \\
\hline & Gezgin & 2 & \\
\hline & Sultan, Bol vakti olan insan & 1 & \\
\hline \multirow{2}{*}{$\begin{array}{l}\text { Olumsuz } \\
\text { İmaj } \\
\text { Metaforları } \\
(n=11)\end{array}$} & Düşkün, mecnun & 2 & \multirow{2}{*}{$\begin{array}{l}\text { Öğretmen bekâr ise etrafında kendine } \\
\text { uygun birilerini arar, cazibe merkezi } \\
\text { konumundadır dikkat çeker, herkese } \\
\text { alıcı gözle bakar, dış görünüşüne } \\
\text { oldukça önem verir. }\end{array}$} \\
\hline & $\begin{array}{l}\text { Eski model araba, Dağınık ev, Şaşkın } \\
\text { ördek, Ruh, Dinç ama eksikleri olan bir } \\
\text { aktör, Ferdi sporcu, Hamal }\end{array}$ & 1 & \\
\hline
\end{tabular}

Tablo 3'te görüldüğü gibi, 12 okul yöneticisi bekâr öğretmenlere ilişkin güç metaforları başlığı altında toplanabilecek on iki metafor üretmiştir. Okul yöneticileri kullandıkları bu metaforların gerekçesi olarak öğretmenin bekâr ise çabalamasını, aktif ve sorunsuz olmasını, öğrenciyle arkadaş gibi olmasını, güçlü ve genç olmasını göstermişlerdir. İki katılımcının kullandıkları metaforlar ve nedenlerini örneklendiren iki ifade aşağıda sunulmuştur.

K 50 (36 yaşında, erkek): Bekâr öğretmenler ögrrenci ile sıkı dost gibidir; çünkü öğrenci ile daha çok vakit geçirir.

K 58 (47 yaşında, erkek): Bekâr öğretmenler atom karınca gibidir; çünkü durmaksızın çabalar.

K 61 (40 yaşında, erkek): Bekar öğretmenler virüssüz bilgisayar gibidir; çünkü sorunsuz çalışırlar.

Yine 12 okul yöneticisi seçicilik metaforları başlığı altında toplanabilecek sekiz metafora yer vermiştir. Bu metaforlardan en fazla tekrarlanan, dört frekans ile radar metaforu olmuştur. Okul yöneticileri kullandıkları bu metaforların gerekçesi olarak öğretmenin bekâr ise etrafında kendisine uygun birilerini aramasını, cazibe merkezi konumunda olmasını, herkese alıcı gözle bakmasını, dış görünüşüne oldukça önem vermesini göstermişlerdir. İki yöneticinin bu konudaki görüşleri şu biçimdedir:

K 9 (33 yaşında, erkek): Bekâr öğretmenler radar gibidir; çünkü kapsama alanına girenleri hemen yakalar.

K 12 (42 yaşında, erkek): Bekâr öğretmenler antenleri açık televizyon gibidir; çünkü herkesle iletişime geçerler.

K 72 (35 yaşında, erkek): Bekâr öğretmenler galerideki araba gibidir; çünkü her an talibine açık olmalıdır.

Tablo 3’te görüldüğü gibi, 11 okul yöneticisi özgürlük metaforları başlığı altında toplanabilecek beş metafor üretmiştir. $\mathrm{Bu}$ metaforların içerisinde en fazla frekansa sahip dört frekans ile turist metaforu olmuştur. Okul yöneticileri kullandıkları bu metaforların gerekçesi olarak öğretmenin bekâr ise zamanının çok olmasını, ekstra çalışmalara zaman 
ayırabilmesini, özgür olmasını, her tatilde bir yere gitmesini, gezgin gibi olanaklara sahip olmasını göstermişlerdir. İki katılımcının kullandıkları metaforları ve bu metaforların kullanılmasının nedenlerini örneklendiren iki ifade aşağıda sunulmuştur.

K 19 (35 yaşında, erkek): Bekar öğretmenler özgür bir kuş gibidir; çünkü her şeye özgürce ayıracağı zamant vardir.

K 23 (38 yaşında, erkek): Bekâr öğretmenler sultan gibidir; çünkü karışanı yoktur.

K 54 (45 yaşıında, erkek): Bekâr öğretmenler turist gibidir; çünkü öğrenmek için gezinir.

Tablo 3'e göre, 11 okul yöneticisi olumsuz imaj metaforları başlığı altında toplanabilecek dokuz metafora yer vermiștir. $\mathrm{Bu}$ metaforların içerisinde en fazla frekansa sahip olanlar iki frekans ile düşkün ve mecnun metaforları olmuştur. Okul yöneticileri kullandıkları bu metaforların gerekçesi olarak öğretmenin bekâr ise bir yuva ve çocuk özlemi içerisinde olmasını, kendine özen göstermemesini, düzensiz bir hayata sahip, okuldaki tüm uğraştırıcı işler kendisine verildiğinden sıkıntılı ve gergin olmasını göstermişlerdir. İki katılımcının kullandıkları metaforları ve bu metaforların kullanılmasının nedenlerini örneklendiren iki ifade aşağıda sunulmuştur.

K 26 (35 yaşında, erkek): Bekâr öğretmenler eski model araba gibidir; çünkü istediğiniz hızı ve verimi yakalayamazsiniz.

K 30 (33 yaşında, erkek): Bekâr öğretmenler dağınık ev gibidir; çünkü kendine özen göstermez.

K 33 (33 yaşında, erkek): Bekâr öğretmenler mecnun gibidir; çünkü Leyla'sını arar.

\subsection{Evli Öğretmenlere İlișkin Metaforlar}

Okul yöneticilerine evli öğretmenleri neye benzettikleri ve bunun nedenleri sorulmuş, üretilen metaforlar Tablo 4 'te verilmiştir.

Tablo 4. Evli Öğretmenlere Yönelik Metaforik Algılar

\begin{tabular}{|c|c|c|c|}
\hline $\begin{array}{l}\text { Metafor } \\
\text { Kategorileri }\end{array}$ & Metaforlar & $f$ & Nedenleri \\
\hline & Yorgun insan & 3 & \\
\hline $\begin{array}{l}\text { Verimsizlik } \\
\text { Metaforları } \\
(n=23)\end{array}$ & $\begin{array}{l}\text { Tren, Yorgun savaş̧̧ı, durgun su } \\
\text { Yıpranmış eşya, Virüslü bilgisayar, } \\
\text { Koyun, Rölantideki araba, Freni } \\
\text { patlamış yokuş aşağı giden kamyon, } \\
\text { Yıkık duvar, Yıkık bir han, 90. dakikada } \\
\text { gol yemiş kaleci, Paçayı kaptırmış } \\
\text { pehlivan, Külkedisi, Fazla yük atılmış } \\
\text { hayvan, İflas etmiş esnaf, Hamal, } \\
\text { Mahkûm }\end{array}$ & 2 & $\begin{array}{l}\text { Çünkü öğretmen eğer evli ise } \\
\text { prangaları vardır, yorgun ve } \\
\text { bitkindir, sabah akşam aynı işleri } \\
\text { yapar, hayattan beklentisi } \\
\text { kalmamıştır, insanlarla iletişimi } \\
\text { keser, zamana yetişemez, hep } \\
\text { ödemeleri düşünür, hayatta } \\
\text { omuzlaması gereken yük artmıştır. }\end{array}$ \\
\hline & Jeneratör & 6 & Öğretmen evli ise kendini bütün \\
\hline $\begin{array}{l}\text { Güç } \\
\text { Metaforları } \\
(n=20)\end{array}$ & $\begin{array}{l}\text { Saat } \\
\text { Takım sporcusu, İsviçre çakısı, Kaplan, } \\
\text { Başarılı işadamı, Muhtar, Orkestra şefi, } \\
\text { Nirvana'ya ulaşmış insan, Hükümet, } \\
\text { Matematikçi, Aslan, Kale, Japon }\end{array}$ & 2 & $\begin{array}{l}\text { hisseder, aktiftir, her zaman } \\
\text { enerjiktir, kendini kanıtlamıştır ve } \\
\text { düzenli bir hayata sahiptir, birden } \\
\text { fazla sorumluluğa sahip olup } \\
\text { hepsinin üstesinden gelmektedir. }\end{array}$ \\
\hline $\begin{array}{l}\text { Duygusallık } \\
\text { Metaforları } \\
(n=15)\end{array}$ & $\begin{array}{l}\text { Anne-baba } \\
\text { Anlayışlı insan, Düşünceli insan } \\
\text { Yorgun ama özverili bir aktör, İkiye } \\
\text { bölünmüş elma, Kedi, Uysal hayvan, } \\
\text { Suçlu İnsan, Durgun deniz, Hamur }\end{array}$ & $\begin{array}{l}4 \\
2\end{array}$ & $\begin{array}{l}\text { Öğretmen eğer evli ise şefkatli, } \\
\text { anlayışlı ve uysaldır, eşinin } \\
\text { korkusundan dolayı kendini suçlu } \\
\text { hisseder ve her duruma adaptasyon } \\
\text { için şekil değiştirir. }\end{array}$ \\
\hline $\begin{array}{l}\text { Koruyuculuk } \\
\text { Metaforları } \\
(n=8)\end{array}$ & $\begin{array}{l}\text { Kartal } \\
\text { Kalkan, Antivirüs, Şemsiye, Civcivleri } \\
\text { koruyan gurk tavuk }\end{array}$ & 1 & $\begin{array}{l}\text { Öğretmen eğer evli ise hem ailesine } \\
\text { hem de öğrencilere karşı } \\
\text { koruyucudur. }\end{array}$ \\
\hline
\end{tabular}


Tablo 4 incelendiğinde, okul yöneticilerinden 23'ünün evli öğretmenlere ilişkin kullandıkları metaforların verimsizlik metaforları başlığı altında toplanabileceği görülmektedir. Yöneticiler bu kapsamda toplam 18 on sekiz metafora yer vermiştir. $\mathrm{Bu}$ metaforların içerisinde en fazla frekansa sahip olanı üç frekans ile yorgun insan metaforu olmuştur. Okul yöneticileri kullandıkları bu metaforların gerekçesi olarak öğretmenin evli ise prangalarının olmasını, yorgun ve bitkin olmasını, sabah akşam aynı işleri yapmasını, beklentilerinin kalmamasını, insanlarla iletişimi kesmelerini, zamana yetişememelerini, hep ödemeleri düşünmelerini, yüklerinin artmasını göstermişlerdir. İki katılımcının kullandıkları metaforlar ve bu metaforların kullanılmasının nedenlerini örneklendiren iki ifade aşağıda sunulmuştur.

K 6 (37 yaşında, erkek): Evli öğretmen freni patlamış yokuş aşă̆ı giden bir kamyon gibidir; çünkü hayat ve sorumluluklar onu yormuştur.

K 19 (35 yaşında, erkek): Evli öğretmen 90. dakikada gol yemiş futbolcu gibidir; çünkü maç bitmiştir ve telafisi yoktur.

K 45 (43 yaşında, erkek): Evli ö̆gretmen mahkûm gibidir; çünkü prangaları vardır.

Tablo 4'te görüldüğü gibi, 20 okul yöneticisi evli öğretmenlere ilişkin güç metaforları başlığı altında toplanabilecek on dört metafor üretmiştir. Bu metaforların içerisinde en fazla frekansa sahip altı frekans ile Jeneratör metaforu olmuştur. Okul yöneticileri kullandıkları bu metaforların gerekçesi olarak öğretmenin evli ise kendisini bütün hissetmesini, aktif, her zaman enerjik, kendisini kanıtlamış olmasını, düzenli bir hayatı olmasını, birden fazla sorumluluğa sahip olmasını göstermişlerdir. İki katılımcının kullandıkları metaforları ve nedenlerini örneklendiren iki ifade aşağıda sunulmuştur.

K 4 (30 yaşında, erkek): Evli öğretmenler Japon gibidir; çünkü hayatı çok düzenli ve programlıdır.

K 12 (35 yaşında, erkek): Evli öğretmenler saat gibidir; çünkü dakiklerdir.
K 57 (55 yaşında, erkek): Evli öğretmenler jeneratör gibidir; çünkü hep enerjiktirler.

Yine Tablo 4'te görülebileceği gibi, 15 okul yöneticisi evli öğretmenlere ilişkin, duygusallık metaforları başlı̆̆ altında toplanabilecek on metafora yer vermiştir. Duygusallık metaforlarından en çok tekrar eden dört frekans ile anne-baba metaforu olmuştur. Okul yöneticileri kullandıkları bu metaforların gerekçesi olarak öğretmenin evli ise şefkatli, anlayışlı, uysal olmasını, eşinin korkusundan dolayı suçlu hissetmesini ve duruma göre şekil değiştirmesini göstermişlerdir. İki katılımcının kullandıkları metaforlar ve bu metaforların kullanılmasının nedenlerini örneklendiren iki ifade aşağıda sunulmuştur.

K 24 (42 yaşında, erkek): Evli öğretmenler düşünceli insan gibidir, hep evini düşünür.

K 29 (42 yaşında, erkek): Evli öğretmenler suçlu gibidir; çünkü hanımının korkusu ile yaşarlar.

K 52 (47 yaşında, erkek): Evli öğretmenler hamur gibidir; çünkü durumlara göre şekil değiştirebilirler.

Diğer taraftan, 8 okul yöneticisi koruyuculuk başlı̆̆ 1 altında toplanabilecek beş metafor kullanmıştır. Bu metaforların içerisinde en fazla frekansa sahip dört frekans ile kartal metaforu olmuştur. Okul yöneticileri kullandıkları bu metaforların gerekçesi olarak öğretmenin evli ise koruyucu ve ilgili olmasını göstermişlerdir. Bir katılımcının kullandığı metafor ve nedeni aşağıda sunulmuştur.

K 12 (35 yaşında, erkek): Evli öğretmenler civcivlerini koruyan gurk tavuk gibidir; çünkü çocukları hayata hazırlar.

K 49 (38 yaşında, erkek): Evli öğretmenler kartal gibidir; çünkü koruyuculardır.

\subsection{Derste Bulunan Öğretmenlere İlişkin Metaforlar}

Okul yöneticilerine derste bulunan öğretmenleri neye benzettikleri ve bunun nedenleri sorulmuş, üretilen metaforlar Tablo 5 'te verilmiştir. 
Tablo 5. Derste Bulunan Öğretmenlere Yönelik Metaforik Algılar

\begin{tabular}{|c|c|c|c|}
\hline $\begin{array}{l}\text { Metafor } \\
\text { Kategorileri }\end{array}$ & Metaforlar & $f$ & Nedenleri \\
\hline $\begin{array}{l}\text { Güç } \\
\text { Metaforları } \\
(n=21)\end{array}$ & $\begin{array}{l}\text { Aslan } \\
\text { Komutan } \\
\text { Arı, Kral, Kaplan, Yargıç } \\
\text { Savaşçı, Işık, Lionel Messi, Meyvesi } \\
\text { olgunlaşmış ağaç, Hüseyin Bolt } \\
\end{array}$ & $\begin{array}{l}5 \\
3 \\
2 \\
1\end{array}$ & $\begin{array}{l}\text { Çünkü öğretmen sınıfta iken sınıfın } \\
\text { tek hâkimidir, itaat bekler, } \\
\text { yöneticidir, üreticidir, yargılayıcıdır, } \\
\text { serttir, güçlüdür ve gayretlidir. }\end{array}$ \\
\hline $\begin{array}{l}\text { Gözdelik } \\
\text { Metaforları } \\
(n=17)\end{array}$ & $\begin{array}{l}\text { Tiyatro sanatçısı } \\
\text { Film yıldızı, sanatçı } \\
\text { Tiyatro sahnesi, Şovmen, İllüzyonist, } \\
\text { Popstar, Beyazıt Öztürk, Sahnedeki } \\
\text { insan }\end{array}$ & $\begin{array}{l}5 \\
3\end{array}$ & $\begin{array}{l}\text { Çünkü öğretmen sınıfta iken tüm } \\
\text { gözler onun üzerindedir, ilgi odağı } \\
\text { olmak ister. }\end{array}$ \\
\hline $\begin{array}{l}\text { Öğreticilik } \\
\text { Metaforları } \\
(n=12)\end{array}$ & $\begin{array}{l}\text { Verici } \\
\text { Bilgisayar } \\
\text { Gayretli insan, Anne, Bilim adamı, } \\
\text { Piyango, Bilge, Profesör, Sözcü }\end{array}$ & $\begin{array}{l}3 \\
2\end{array}$ & $\begin{array}{l}\text { Öğretmen sınıfta iken anlattıklarının } \\
\text { etkili olabilmesi için çaba harcar, } \\
\text { durmadan öğretmeye çalışır, kalıcı } \\
\text { bir öğrenme için rolden role girer, } \\
\text { ödüller dağıtır ve ilgi çekmek için her } \\
\text { yolu dener. }\end{array}$ \\
\hline $\begin{array}{l}\text { Önderlik } \\
\text { Metaforları } \\
(n=9)\end{array}$ & $\begin{array}{l}\text { Kaptan, lokomotif, orkestra şefi } \\
\text { Kervanın önündeki baş deve, Komutan, } \\
\text { Yönetmen }\end{array}$ & 1 & $\begin{array}{l}\text { Çünkü öğretmen derste iken } \\
\text { öğrencileri devamlı sevk eder, yol } \\
\text { gösterir, arkasından bir grubu } \\
\text { götürür, kendisi nereye giderse } \\
\text { öğrencileri de oraya gider. }\end{array}$ \\
\hline $\begin{array}{l}\text { Olumsuz İmaj } \\
\text { Metaforları } \\
(n=5)\end{array}$ & Telefon, Mikrofon, Saat bekçisi & 1 & $\begin{array}{l}\text { Öğretmen derste iken sürekli } \\
\text { konuşur, her şeyi bildiğini ve tüm } \\
\text { alıcıların ona ayarlı olduğunu } \\
\text { zanneder, çok uğraşır ve saatin } \\
\text { dolmasını bekler. }\end{array}$ \\
\hline
\end{tabular}

Tablo 5'te görüldüğü gibi, 21 okul yöneticisi sinıfta bulunan öğretmenlere ilişkin güç metaforları başlığı altında toplanabilecek on iki metafor üretmiştir. Bu metaforlardan en çok tekrarlananı aslan metaforu olmuştur. Bunu, komutan, arı, kral ve kaplan metaforları takip etmiştir. Okul yöneticileri kullandıkları bu metaforların gerekçesi olarak öğretmenin sınıfta iken sınıfın tek hâkimi olmasını, itaat beklemesini, yönetici, üretici ve yargılayıcı olmasını, sert, güçlü ve gayretli olmasını göstermişlerdir. İki katılımcının kullandıkları metaforlar ve bu metaforların kullanılmasının nedenlerini örneklendiren iki ifade aşağıda sunulmuştur.

K 5 (30 yaşında, erkek): Dersteki öğretmen arı gibidir; çünkü tek tek herkesi işler.

K 22 (35 yaşında, erkek): Dersteki öğretmen komutan gibidir; çünkü 40 dakikada savaşı kazanacak gayreti göstermeye çalışır. K 28 (42 yaşında, erkek): Dersteki öğretmen yargıç gibidir; çünkü hüküm verir, yargılar.

Okul yöneticilerinden 17'si gözdelik metaforları başlığı altında toplanabilecek dokuz metafor üretmiştir. Tiyatro sanatçısı metaforu en çok tekrarlanan metafor olmuştur. Film yıldızı ve sanatçı metaforu üç frekansla tiyatro sanatçısı metaforunu izlemiştir. Okul yöneticileri kullandıkları bu metaforların gerekçesi öğretmenin sınıfta iken tüm gözlerin onların üzerinde olmasını, ilgi odağı olmak istemesini, derste odak noktasındaki insan olmasını göstermişlerdir. İki katılımoının kullandıkları metaforları ve bu metaforların kullanılmasının nedenlerini örneklendiren iki ifade aşağıda sunulmuştur.

K 25 (42 yaşında, erkek): Dersteki öğretmen film yıldızı gibidir; çünkü ortamda sadece o vardır.

K 30 (33 yaşında, erkek): Dersteki ö̆retmen film yıldızı gibidir; çünkü tüm gözler onun üzerindedir. 
K 63 (42 yaşında, erkek): Dersteki öğretmen tiyatro sahnesi gibidir; çünkü ders anlatırken hayatı bir kenara bırakır.

Okul yöneticilerinden 12'si öğreticilik metaforları başlığı altında toplanabilecek dokuz metafor kullanmıştır. Bu metaforların içerisinde en fazla frekansa sahip üç frekansla verici metaforu olmuştur. Verici metaforunu iki frekansla bilgisayar metaforu takip etmiştir. Okul yöneticileri kullandıkları bu metaforların gerekçesi olarak öğretmenin sınıfta iken anlattıklarının etkili olabilmesi için çaba harcamasını, durmadan bir şeyler öğretmeye çalışmasını, kalıcı bir öğrenme için rolden role girmesini ve ilgi çekmek için çaba harcamasını göstermişlerdir. İki katılımcının kullandıkları metaforlar ve bu metaforların kullanılmasının nedenlerini örneklendiren iki ifade aşağıda sunulmuştur.

K 21 (42 yaşında, erkek): Dersteki öğretmen piyango gibidir; çünkü derste öğreterek ödül vermeye çalışır.

K 22 (35 yaşında, erkek): Dersteki öğretmen bilge gibidir; çünkü kendisi öğrenciler arasında en fazla bilendir.

K 52 (47 yaşında, erkek): Dersteki öğretmen bilgisayar gibidir; çünkü bilgileri en etkili şekilde aktarmaya çalışır.

Tablo 6'da görüldüğü gibi okul yöneticilerinden 9'u, önderlik metaforları başlığı altında toplanabilecek altı metafora yer vermiştir. $\mathrm{Bu}$ metaforlardan kaptan, lokomotif ve orkestra şefi metaforları ikişer yönetici tarafından dile getirilmiştir. Okul yöneticileri kullandıkları bu metaforların gerekçesi olarak öğretmenin sınıfta iken öğrencileri devamlı sevk etmesini, yol göstermesini, arkasından bir grubu götürmesini, kendisi nereye giderse öğrencilerin de oraya gitmesini göstermişlerdir. İki katılımcının kullandıkları metaforlar ve bu metaforların kullanılmasının nedenlerini örneklendiren iki ifade aşağıda sunulmuştur.

K 14 (29 yaşında, erkek): Dersteki öğretmen komutan gibidir; çünkü ögrrencileri sevk ve idare eder.

K 20 (47 yaşında, erkek): Dersteki öğretmen kaptan gibidir; çünkü ilim denizinde öğrencileri ile yol alır.

K 21 (42 yaşında, erkek): Dersteki öğretmen yönetmen gibidir; çünkü öğrencileri duruma göre yönlendirir.
Tablo 6 incelendiğinde olumsuz imaj metaforları başlı̆̆ı altında toplanabilecek dört metafora yer verildiği görülmektedir. $\mathrm{Bu}$ kategorideki metaforlardan en fazla iki frekansla tezgahtar metaforu kullanılmıştır, geriye kalan metaforların frekansları bir olarak tespit edilmiştir. Okul yöneticileri kullandıkları bu metaforların gerekçesi öğretmenin sınıfta iken durmadan konuşmasını, kendisini öğrenciler arasında en fazla bilen görmesini, çok çabalamasını ve zamanın dolmasını beklemesini göstermişlerdir.

İki katılımcının kullandıkları metaforları ve bu metaforların kullanılmasının nedenlerini örneklendiren iki ifade aşağıda sunulmuştur.

K 2 (32 yaşında, erkek): Dersteki öğretmen telefon gibidir; çünkü derste durmaksızın sadece konuşur. K 25 (42 yaşında, erkek): Dersteki öğretmen tezgâhtar gibidir; çünkü ürünlerini pazarlamaya çalışır.

K 56 (26 yaşında, erkek): Dersteki öğretmen saat bekçisi gibidir; çünkü zamanın dolmasını bekler.

\section{TARTIŞMA}

$\mathrm{Bu}$ araştırmada okul yöneticilerinden mesleğinin çeşitli dönem ve durumlarındaki öğretmenlere ilişkin algılarını metaforlar yoluyla betimlemeleri istenmiştir. Bu kapsamda yöneticiler; göreve yeni başlayan, emekliliği yaklaşmış, bekâr, evli ve derste bulunan öğretmenlere ilişkin algılarını metaforlar yoluyla dile getirmişlerdir.

Okul yöneticileri mesleğinin ilk yıllarındaki öğretmenleri acemi, güçlü ve verimli ve idealist olarak görmektedirler. Bu algilardan daha çok öne çıkan ise ilk yılarlıdaki öğretmenleri acemilikleri olmuştur. Yılmaz, Göçen ve Yılmaz'ın (2013) öğretmen adaylarının öğretmenlere ilişkin metaforik algılarını belirlemeye yönelik çalışmasında öğretmen adayları "kahraman, 1şık, fener, kutsal bir varlık, yeni doğan bebek, ceylan, üstün bir kişi, usta" gibi metaforlar kullanmışlardır. Bu metaforlar bu araştırmada ortaya çıkan acemilik, güç ve verimlilik ve idealizm metaforlarını desteklemektedir. Öğretmenler mesleğe ilişkin birçok gerekliliği göreve başladıkları okullarda öğrenmektedir. Hizmet öncesinde okul deneyimi ve öğretmenlik uygulamalarının kısa süreli olması bu acemiliğin önemli nedenlerinden biri olarak düşünülebilir. Okul yöneticileri öğretmeni ilk yıllarında acemiliğinin yanı sıra güçlü ve 
verimli ve idealist olarak betimlemektedir. Göreve yeni başlayan öğretmenlerin güçlü ve verimli olarak algılanması gençliği ile ilişkilendirilmektedir. Bu öğretmenlerin idealist olarak algılanmaları ise daha çok ironik biçimde ele alınmıştır. Yöneticilere göre göreve yeni başlayan öğretmenler her şeyi bildiğini ve yapabileceğini zannetmektedir ama durum böyle değildir. Yeni öğretmenlerin hem acemi hem de idealist olarak nitelenmesi de bu çıkarımı desteklemektedir.

Araştırmaya katılan okul yöneticileri emekliliğine yaklaşan öğretmenleri daha çok verimsiz olarak algilamaktadır. Okul yöneticilerinin kullandıkları "akkoru geçecek lamba, bozuk plak, uzatmaları oynayan futbolcu" metaforları bu algıyı açıklamaktadır. Verimsizlik metaforuna yakın sayılabilecek bir çoğunlukla da okul yöneticilileri emekliliğ̆i yaklaşmış öğretmenleri yılların getirdiği tecrübe ve birikimle güçlü olarak algilamaktadırlar. Aslında emekliliği yaklaşmış öğretmenler aynı zamanda uzun yıllar boyunca emek ve hizmet vermenin getirdiği uzmanlıkla da dikkat çekmektedir. Dolayısıyla okul yöneticileri "ansiklopedi, köklü çınar, uzman insan" metaforlarını kullanmışlardır. Sönmezer' in (2007) bulguları, özel okullarda çalışan öğretmenlerin yarıya yakınının emeklilik sonrası bu okullarda çalışmaya başladıklarını göstermektedir. Öğretmenlerini seçmekte görece seçici davranan özel okulların emekli öğretmenleri bu oranda tercih etmesi bu araştırmada öne çıkan "uzman insan", "köklü çınar" gibi metaforlarla uyum göstermektedir. Okul yöneticileri emekliği yaklaşan öğretmenleri aynı zamanda duygusal olarak betimlemektedir. Okul yöneticileri bekâr öğretmenleri güçlü, eş arayan ve özgür olarak betimlerken bu öğretmenlere ilişkin kimi olumsuz algılarını da metaforlarla dile getirmişlerdir. Okul yöneticilerinin algılarına göre bekâr öğretmenler hem genç hem de vakitleri bol olduğundan güçlü halleriyle dikkat çekmektedirler. Bu anlamda bekâr öğretmenler "atom karınca" metaforuyla betimlenmiştir. Okul yöneticileri bekâr öğretmenlerin bakımlı olmasını çoğunlukla evlenme isteğine yönelik bir eylem olarak algılamaktadır. Bu algıyı "tavus kuşu, galerideki araba, aday damat" metaforlariyla belirlemek mümkündür. Ayrıca dağınık ruh halleri ve daha çok duygusal hayatları ile de dikkat çekmektedirler. Bekâr öğretmenleri seçicilik teması altında "radar, magazin muhabiri, avcı" olarak kavramsallaştıran okul yöneticileri özgürlük teması altında "turist, sultan" gibi metaforlar kullanmışlardır. Ayrıca okul yöneticileri bekâr öğretmenleri "düşkün, mecnun" gibi olumsuz olarak değerlendirilen metaforlarla da betimlemişlerdir.

Okul yöneticileri evli öğretmenleri bir yandan verimsiz olarak betimlerken bir yandan da güçlü yanlarına vurgu yapmaktadır. Bunun yanında evli öğretmenler duygusal ve koruyucu olarak nitelendirilmektedir. Bazı okul yöneticilerine göre evli olmak öğretmenler için bir güçtür. Belirli disiplinle yaşamaya alışmış evli öğretmenler daha pratik, daha özverili ve daha kendinden emin bir şekilde sakinlikleriyle dikkat çekmektedirler. "Jeneratör" ve "İsviçre çakısı" metaforları bu durumun göstergesidir. Gülererli (2014), öğretmenlerin evlilik uyumları ile yaratıcılıkları arasındaki ilişkiyi inceledikleri çalışmada öğretmenlerin evlilik süresi değişkenine göre yaratıcılık puanlarının anlamlı bir farklılık gösterdiğini ve bu farklılığın evlilik süresi uzun olan grup lehine olduğunu tespit etmiştir. Bu durum okul yöneticilerinin evli öğretmenlere yönelik ürettikleri güç metaforlarını desteklerken, bu öğretmenlerin verimsiz olduklarına yönelik algıları ile çelişmektedir. Çelik'e göre (2006), okul yöneticilerinin evlilik doyumları arttıkça mesleki tükenmişlikleri azalmaktadır. Tükenmişliğin bir boyutu da mesleğe yönelik başarı algısıdır. Buradan yola çıkarak iyi bir evliliğin mesleki başarıyı da olumlu etkileyebileceği düşünülebilir. $\mathrm{Bu}$ durumun tersi de düşünülebilir. Tatman, Hovestadt, Yelsma, Fenell, David, ve Canfield'ın (2006) belirtiği gibi, ailesel sorumlulukları yerine getirememek ve bir ebeveyn olarak fazla sorumluluk almak da iş yaşamını olumsuz etkileyebilmektedir. Böylelikle evli olmak öğretmenler açısından evliliklerine ilişkin algılarına göre mesleklerine olumlu ya da olumsuz yansiyor olabilir. Aynı zamanda evli öğretmenler, okul yöneticileri tarafından öğrencilere koruma içgüdüsüyle yaklaşan, duygusal bireyler olarak algılanmaktadır. Oluşturulan "anne-baba" ve "gurk tavuk" metaforları bu algiyı desteklemektedir. Farrell'in (2006) araştırması, Singapur'da öğretmenlere yönelik üretilen metaforlardan birinin "anne" metaforu 
olduğunu göstermektedir. Yine bu bulguyu destekler biçimde, Cerit (2008) de araştırmasında okul yöneticilerinin öğretmenlere yönelik annebaba metaforuna büyük oranda katıldıklarını tespit etmiştir. Erden'in (2016) araştırması ise öğretmenlere yönelik ebeveyn algisının öğretmenlerin öğrenciler üzerindeki etkisine olumlu katkı yapmadığını, hatta durumun tam tersi olduğunu göstermiştir. Öğrenciler öğretmenlerini daha çok öğretimsel alandaki liderlikleri ile görmek istemektedirler.

Araştırmaya katılan okul yöneticilerinin ürettikleri metaforlar incelendiğinde, yöneticilerin derste bulunan öğretmenleri güçlü, gözde, öğretici ve önder olarak gördükleri anlaşılmaktadır. Bunun yanında kimi yöneticilerin dersteki öğretmenlere ilişkin olumsuz algılarının da olduğu görülmektedir. Aydoğdu'ya (2008) göre, öğretmen derste sadece öğreticilik rolü olan bir çalışan olarak görülmemelidir. Öğretmen aynı zamanda yüksek prestij sahibi ve emeğinin karşılığını alan biri olarak görülmelidir. Bu araştırmada da dersteki öğretmenler okul yöneticilerinin dikkatini daha çok güçlü imajları, öğreticilik ve gözdelik yönleriyle çekmektedir. Dersteki öğretmeni öğretici olarak kavramsallaştıran okul yöneticileri, öğretmenlerin bir şeyler öğretebilmek için bir tiyatrocu gibi çaba sarf ettiklerini, bir illüzyonist gibi dikkat çekmeye çalıştıklarını düşünmektedirler. "Film yıldızı" ve "sahnedeki insan" metaforlarını kullanan okul yöneticileri dersteki öğretmenlerin hep ilgi odağı olduğunu düşünmektedirler. Tobin'in (1990) araştırması dersteki öğretmenin bir yönüyle "komedyen" olarak algılandığını göstermektedir. Buna göre öğretmen derste yaptırdığı etkinlikleri eğlenceli hale getirmekle görevlidir. Benzer biçimde Ben-Peretz, Mendelson ve Kron'un (2003) araştırması da öğretmenin sınıf içi görevlerinden birinin öğrencileri eğlendirerek etkinlikleri gerçekleştirmek olduğunu göstermiştir. Bunun yanında Pineau (1994), öğretmenliği "aktör", "artist" gibi yalnızca performans merkezli metaforlarla betimlemenin gerçek sınıf ve eğitim ortamını doğru anlamak noktasında bazı kısıtları beraberinde getirdiğini vurgulamaktadır. Böylesi bir yaklaşım, öğrenci etkinliklerini ve performansını geri plana atmakla eleştirilmektedir. Berliner (1990) öğretmenin sınıfta birçok olaya, insana yön verip birçok görevi yerine getirebildiği için öğretmene en uygun metaforun "yöneticilik" olduğunu savunmaktadır (Akt. Aydoğdu, 2008). Araştırmada bazı okul yöneticilerine göre dersteki öğretmenler önder ruhlarından dolayı öğrencileri istedikleri yöne çevirebilmektedirler ve derste birçok şeyden fedakârlıkta bulunmaktadırlar. Dersteki öğretmenleri bencil olarak algılayan okul yöneticileri bulunmaktadır. $\mathrm{Bu}$ okul yöneticilerine göre, derse giren öğretmenler sadece kendi çocuklarının iyiliğini düşünmekte ve derste saat bekçiliği yapmaktadırlar. Okul yöneticilerinin bir kısmı ise derste bulunan öğretmenlerin çok şey bildiklerini sanıp durmadan konuştuklarını ifade etmektedirler.

\section{Kaynakça}

Akın, U. ve Oğuz, E. (2010). Öğretmenlerin işkoliklik ve tükenmişlik düzeylerinin ilişkisi ve çeşitli değişkenler açısından incelenmesi. Kuram ve Uygulamada Ĕ̆itim Yönetimi, 16(3), 309-327.

Arıkan, İ. (2012). Öğreten Öğretmen Öğrenen Öğrenci. http://www.mef.k12.tr/assets/images/ebook/ibrahim-arikan-kitap01/ adresinden erişilmiştir.

Aydoğdu, E. (2008). İlköğretim Okullarındaki Öğrenci ve Öğretmenlerin Sahip Oldukları Okul Algılarn ile İdeal Okul Algılarının Metaforlar (Mecazlar) Yardımıyla Analizi. Yayımlanmamış yüksek lisans tezi. Osmangazi Üniversitesi Fen Bilimleri Enstitüsü, Eskişehir.

Aydın, İ. S. ve Pehlivan, A. (2010). Türkçe öğretmeni adaylarının “öğretmen” ve "öğrenci" kavramlarına ilişkin kullandıkları metaforlar. Turkish Studies, 5(3), 818-842.

Balcı, A. (1992). Eğitim örgütlerine yeni bakış açıları: Kuram-araştırma ilişkisi. Ankara Üniversitesi Ĕ̆itim Bilimleri Fakültesi Dergisi, 25(1), 47-68.

Balc1, A. (1999). Metaphorical images of school: School perceptions of students, teachers parents from selected schools (In Ankara). Yayımlanmamış doktora tezi. Ortadoğu Teknik Üniversitesi, Ankara. 
Ben-Peretz, M., Mendelson, N. ve Kron, F. W. (2003). How teachers in different educational contexts view their roles. Teaching and Teacher Education 19, 277-290.

Bilgin, N. (2000). İcerik Analizi. İzmir: Ege Üniversitesi Edebiyat Fakültesi Yayınları.

Binbaşıŏlu, C. (2005). Türk Eğitim Düşüncesi Tarihi. Ankara: Anı Yayınları.

Bircan, İ. (21-23 Mayıs 2003). Eğitimde Yeni Yönelimler Gelişmiş Ülkelerde Sınıf Öğretmeni Yetiştirme Uygulamaları. Ĕ̆itimde Yansımalar: VII Çağdaş Eğitim Sistemlerinde Öğretmen Yetiştirme Seтроzуити. Cumhuriyet Üniversitesi Kültür Merkezi, Sivas.

Cerit, Y. (2008). Öğretmen Kavramı İle İlgili Metaforlara İlişkin Öğrenci, Öğretmen Ve Yönetici Görüşleri. Türk Ĕ̆itim Bilimleri Dergisi, 6(4), 693-712.

Clarken, R. H. (24-28 Mart 1997). Five Metaphors for Educators. Paper Presented at the Annual Meting of the American Educational Research Association. Chicago, USA.

Çelik, C. (2006). Eğitim Yöneticilerinin Mesleki Tükenmişlikleri İle Evlilik Doyumları Arasındaki İlişki. Yayımlanmamış Yüksek Lisans Tezi. Gaziosmanpaşa Üniversitesi Sosyal Bilimler Enstitüsü, Tokat.

Çelikten, M. (2006). Kültür ve Öğretmen Metaforları. Erciyes Üniversitesi Sosyal Bilimler Enstitüsü Dergisi, 2, 269-283.

Çelikten, M., Şanal, M. ve Yeni, Y. (2005). Öğretmenlik Mesleği ve Özellikleri. Erciyes Üniversitesi Sosyal Bilimler Enstitüsü Dergisi, 19(2), 207-237.

Demirbolat, A. (2006). Sınıf Ortamı ve Grup Etkileşimi. L. Küçükahmet (Editör). Sınıf Yönetimi (s.42-66). Ankara: Nobel.

Erden, H. (2016). Pre-service Teachers' Perceptions on Being a Teacher Through a Metaphoric Perspective. Anthropologist, 24(1), 134-147.

Eren, A. ve Tekinarslan, E. (2013). Prospective teachers' metaphors: Teacher, teaching, learning, instructional material and evaluation concepts. International J. Soc. Sci. \& Education, 3(2), 435-445.

Farrell, T. S. (2006). 'The teacher is an octopus': Uncovering preservice English language teachers' prior beliefs through metaphor analysis. Regional Language Centre Journal, 37(2), 236-248.

Gelbal, S. ve Duyan, V. (2010). İlköğretim öğretmenlerinin çocuk sevme durumlarına etki eden değişkenlerin incelenmesi. Hacettepe Üniversitesi Ĕ̆itim Fakültesi Dergisi, 38, 127-137.

Girmen, P. (2007). İlköğretim öğrencilerinin konuşma ve yazma sürecinde metaforlardan yararlanma durumları. Yayımlanmamış doktora tezi. Anadolu Üniversitesi Eğitim Bilimleri Enstitüsü, Eskişehir.

Gülererli, N. (2014). Öğretmenlerin Evlilik Uyumları ile Yaratıcılıkları Arasındaki İlişkinin İncelenmesi. (Beylikdüzü Örneği). Yayımlanmamış yüksek lisans tezi. Marmara Üniversitesi Eğitim Bilimleri Enstitüsü, İstanbul.

Kalağan, G., \& Güzeller, C. O. (2010). Öğretmenlerin Örgütsel Sinizm Düzeylerinin İncelenmesi. Pamukkale Üniversitesi Ĕ̆itim Fakültesi Dergisi, 27, 83-97.

Kalyoncu, R. (2012). Görsel Sanatlar Öğretmeni Adaylarının “Öğretmenlik" Kavramına İlişkin Metaforlar1. Mustafa Kemal Üniversitesi Sosyal Bilimler Enstitüsü Dergisi, 9(20), 471-484.

Karagözoğlu, G. (21-23 Mayıs 2003). Eğitim Sistemimizde Öğretmen Yetiştirme Politikamıza Genel Bir Bakış. Eğitimde yansımalar: VII Çă̆daş Eğitim Sistemlerinde Öğretmen Yetiştirme Sempozyumu. Cumhuriyet Üniversitesi Kültür Merkezi, Sivas.

Kurşunoğlu, A., Bakay, E. ve Tanrı̈ğgen, A. (2010). İlköğretim Okulu Öğretmenlerinin Örgütsel Bağllılı Düzeyleri. Pamukkale Üniversitesi Ĕ̆itim Fakültesi Dergisi, 28(28), 101-115.

Lakoff, G. ve Johson, M. (1980). Metaphors we live by. Chicago: University of Chicago press.

Levine, P. M. (25-27 Ekim 2001). Our Past Informs the Present: Metaphors and Images of Classrooms. Paper presented at the Annual Conference of the Woman of Appalachia: Their Heritage and Accomplishments. West Virginia State College.

Morgan, G. (1997). Yönetim ve Örgüt Teorilerinde Metaphor. (Çev: Gündüz Bulut ve Zülfü Dicleli). İstanbul: MESS Yayınları (Eserin Orjnali 1986'da yayımlandı). 
Mustan, T. (2002). Dünyada ve Türkiye'de Öğretmen Yetiştirmede Yeni Yaklaşımlar. Kuram ve Uygulamada Ĕ̆itim Yönetimi. 29, 115-127.

Ocak, G. ve Gündüz, M. (2006). Eğitim Fakültesini Yeni Kazanan Öğretmen Adaylarının Öğretmenlik Mesleğine Giriş Dersini Almadan Önce ve Aldıktan Sonra Öğretmenlik Mesleği Hakkındaki Metaforlarının Karşılaştırılması. Afyon Kocatepe Üniversitesi Sosyal Bilimler Dergisi, 8(2), 293-309.

Oğuz, A. (2009). Öğretmen Adaylarına Göre Ortaöğretim Öğretmenlerini Temsil Eden Metaforlar. Milli Ĕ̈itim, 38(182), 36-57.

Ortony, A., Reynolds, R.E. ve Arter, J.A. (1978). Metaphor: Theoretical and Empirical Research. Psychological Bulletin, 85(5), 919-943.

Patchen, T. ve Crawford, T. (2011). From Gardeners To Tour Guides: the Epistemological Struggle Revealed in Teacher-Generated Metaphors of Teaching. Journal of Teacher Education, 62(3), 286298.

Pektaş, M. ve Kıldan, A.O. (2009). Farklı Branşlardaki Öğretmen Adaylarının “Öğretmen” Kavramı ile İlgili Geliştirdikleri Metaforların Karşılaştırılması. Erzincan Eğitim Fakültesi Dergisi, 11(2), 271-287.

Pineau, E. L. (1994). Teaching is performance: Reconceptualizing a Problematic Metaphor. American Educational Research Journal, 31(1), 3-25.

Saban, A. (2004). Giriş Düzeyindeki Sınıf Öğretmeni Adaylarının “Öğretmen” Kavramına İlişkin İleri Sürdükleri Metaforlar. Türk Ĕ̆itim Bilimleri Dergisi, 2(2), 131-155.

Saban, A. (2011). Bilgisayar Öğretmeni Adaylarının “Okul” ve “Bilgisayar Öğretmeni” Kavramlarına İlişkin Zihinsel İmgeleri. Kuram ve Uygulamada Ĕ̆itim Bilimleri, 11(1), 423-446.

Saban, A. (2008). Okula İlişkin Metaforlar. Kuram ve Uygulamada Ĕ̆itim Yönetimi, 55, 459-496.

Saban, A., Koçbeker, B. N. ve Saban, A. (2006). Öğretmen Adaylarının Öğretmen Kavramına İlişkin Algılarının Metafor Analizi Yoluyla İncelenmesi. Kuram ve Uygulamada Ĕ̆itim Bilimleri, 6(2), 461522.

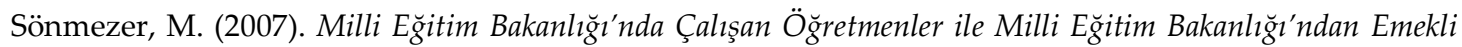
veya İstifa Nedeniyle Özel Ĕ̆itim Kurumlarında Çalışanların İş Tatmin Düzeylerinin Karşılaştırmalı Analizi. Yayımlanmamış doktora tezi. İstanbul Üniversitesi Sosyal Bilimler Enstitüsü, İstanbul.

Tatman, A.W., Hovestadt, A.J., Yelsma, P., Fenell, P., David, L., \& Canfield, B.S. (2006). Work and Family Conflict: An often Overlooked Issue in Couple and Family Therapy. Contemporary Family Therapy, 28(1), 39-51.

Tobin, K. (1990). Changing Metaphors and Beliefs: A Master Switch for Teaching?. Theory into Practice, 29(2), 122-127.

Tobin, K. ve Tippins, D. J. (1996). Metaphors as Seeds for Conceptual Change and the Improvement of Science Teaching. Science Education, 80(6), 711-730.

Topses, G. (2006). Öğrenci Davranışlarını Etkileyen Toplumsal ve Psikolojik Etmenler ve Sorunlar. L. Küçükahmet (Editör). Sınıf Yönetimi. (s.12-40). Ankara: Nobel.

Yaman, E., Yaman, H. ve Eskicumalı, A. (2001). Öğretmenlik Mesleğinin Sosyo-Ekonomik Statüsü ve Bu Mesleğin Bir Kadın Mesleği Haline Dönüşmesi Üzerine Bir Araştırma. Sakarya Üniversitesi Eğitim Fakültesi Dergisi, 1(2), 53-68.

Yıldırım, A. ve Şimşek, H. (2011). Sosyal Bilimlerde Nitel Araştırma Yöntemleri. Ankara: Seçkin Yayıncılık.

Yıldırım, A., Ünal, A. ve Çelik, M. (2011). Öğretmen Kavramına İlişkin Öğretmen, Yönetici Ve Müfettiş Algilarının Analizi. Uluslararası Insan Bilimleri Dergisi, 8(2), 92-109.

Yılmaz, F. Göçen, S. ve Yılmaz, F. (2003). Öğretmen Adaylarının Öğretmen Kavramına İlişkin Algıları: Bir Metaforik Çalışma. Mersin Üniversitesi Ĕ̆itim Fakültesi Dergisi. 9(1), 151-164. 


\section{EXTENDED SUMMARY}

Education is the most critique process that enhances human beings in the way to become a person. Human beings are exposing to education in all stages of their life. Teachers are the most critique element of education (Arrkan, 2012). Teaching is not a profession that can be succeeded by everyone. But teaching as a profession, perceived as a work can be made by everyone who could not find a job in other fields and disappointed in life (Karagözoğlu, 2003). Although more recently teaching is perceived as a blessed profession nowadays it has become a work that parents say "our children, at least, may become a teacher". In Turkey teaching is perceived as an "easy job" and "a work with long holidays" by a part of community. It can be asserted that teaching has a negative image in views of Ministry of National Education, parents, students, community, and also school administrators. In this research, it is aimed to determine the existing teacher perceptions of school administrators who are probably the people know teachers well as compared to the others through metaphors.

Metaphor means some kind of thinking and perceiving style that affect people's comprehension of world (Morgan, 1997, 14). It is said that metaphor is a rhetoric tool which arise with Aristotle in the fourth century BC (Clarken, 1997). Metaphors have a great role in shaping individuals conceptual frameworks (Lakoff and Johnson, 1980, 103). Metaphors help to see an existing phenomenon from a different perspective (Levine, 2001). Also metaphors enable to see the complex and discrete things from a new view and help to transfer some features from known concept to unknown ones (Balc1, 1992). They garnish the expression and people have pleasure to discover the mean lying under the metaphor (Ortony, Reynolds and Arter, 1977).

Metaphoric analyses are used as analytic and descriptive tools to search and understand the existing education practices (Balc1, 1999, 35). Metaphors are also used to determine the teacher perceptions of different education shareholders. Clarken (1997) found that the most used metaphors for teachers were friend, authoritarian bass, family, gardener, prophet, and doctor. Patchen and Crawford (2011) determined that teachers were described as individuals who create a product (e.g. artist), perform a role (e.g. Oscar-winning role), and try to reach a target (e.g. mountain climber). In Turkey Saban (2004) found that candidate classroom teachers describe teachers via gardener metaphor. Çelikten (2006), in his cultural research, determined that friend, strict authority, parent, gardener, oyster, and doctor metaphors are mostly used to describe teachers. In literature there are researches examining teacher candidates' metaphorical perceptions about teachers (Aydın and Pehlivan, 2010; Kalyoncu, 2012; Ocak and Gündüz, 2006; Oğuz, 2009; Pektaş and Kıldan, 2009; Saban, 2011; Saban, Koçbeker, and Saban, 2006). From those the research conducted by Ocak and Gündüz (2006) showed that teacher candidates' consciousness level about teaching differentiates their teacher perception. Teacher candidates prefer to use gardener and sun metaphors after they participated to Introduce to Teaching Profession class, while they were using parent metaphor before this class.

Metaphors generated by school administrators showed that they perceive teachers as devoted, illuminating, formative, and also unauthorized (Yıldırım, Ünal, and Çelik, 2011). In the study conducted by Cerit (2008), a great amount of school administrators perceive teachers as angel, knowledge source, parent, friend, producer, guide, gardener, advisor, and sculptor. On the other hand most of the participants refused to describe teachers via negative metaphors like as caretaker, judge, coach, and guardian. We think that there is a gap in research that examines teacher metaphors for different contexts (new beginning or about retirement). There may be different metaphorical perceptions for various teacher groups. The aim of this research is to determine the teacher perceptions of school administrators through metaphors for new beginning, about retirement, single, married, and in-class teachers. 
Phenomenological design was utilized in this research in which qualitative method was preferred. Study group is consisted of 73 school administrators working at Tokat and Eskişehir in the 2013-2014 academic years, fall semester. Data was gathered through the interview form which was developed for this research and face to face interviews were conducted. It is asked to administrators that to what were they liken (1) new beginning, (2) about retirement, (3) single, (4) married, and (5) in-class teachers and why.

Our findings show that, the metaphors school administrators generated for new beginning teachers are grouped under the themes of novice, powerful-productive, and idealist. Teachers about retirement are perceived unfruitful on one hand, powerful and emotional on the other hand. While participants described single teachers as powerful, selective, and free; married teachers are characterized as unfruitful and one hand and powerful on the other hand, also emotional and protective in the same time. The metaphors school administrators generate for teachers in the classroom showed that these teachers are perceived as powerful, favorite, didactic, and leader. 